\title{
PENGARUH TERAPI AKTIVITAS TERHADAP ANSIETAS PADA LANSIA DI PANTI JOMPO TRESNA WERDHA ABDI DHARMA ASIH KOTA
}

\author{
Tinah \\ Poltekkes Kemenkes Medan \\ Email : tinarangkuti75@gmail.com
}

\begin{abstract}
ABSTARCT
Anxiety is one of the most common mental health problems in the elderly. The provision of appropriate and accurate psychopharmacology as well as nursing therapy is not enough, but must be followed up with selected therapy modalities regularly and continuously until the normal functioning of stable normative behavior or adaptive behavior, one of which is group activity therapy. To determine the effect of group activity therapy on the level of anxiety in the elderly. The design of this study is a quasi-experimental design with a pre-post test group design with a total sample of 44 people. The independent variable is group activity therapy (TAK) and the dependent variable is anxiety. The instruments used are questionnaire sheets and observation sheets. The statistical test used the Wilcoxon test with a significance value of $=0.05$. The anxiety level of the majority of the elderly before TAK therapy was severe anxiety as much as $40.91 \%$ and after TAK therapy the majority of the elderly with mild anxiety level as much as $47.73 \%$. There was a difference in anxiety before and after giving group activity therapy with a $P$ value of 0.000 ( $\mathrm{P}<0.05$ ). Group activity therapy has an effect on reducing anxiety levels in the elderly.
\end{abstract}

Keywords : Anxiety, elderly, group activity therapy

\begin{abstract}
ABSTRAK
Kecemasan termasuk salah satu masalah kesehatan jiwa yang paling sering muncul pada lansia. Pemberian terapi baik psikofarmakologi maupun keperawatan yang tepat dan akurat saja tidak cukup, tetapi harus disusul dengan terapi modalitas yang dipilih secara teratur dan kontinu sampai berfungsinya kembali perilaku normatif yang stabil atau perilakunya adaptif, salah satunya dengan terapi aktivitas kelompok. Untuk mengetahui pengaruh terapi aktivitas kelompok terhadap tingkat kecemasan pada lansia. Design penelitian ini yaitu quasi experiment dengan rancangan pre-post test group design dengan jumlah sampel 44 orang. Variabel independen terapi aktivitas kelompok (TAK) dan variabel dependen adalah kecemasan. Instrument yang digunakan adalah lembar kuesioner dan lembar observasi. Uji statistik menggunakan uji Wilcoxon dengan nilai kemaknaan $\alpha=0,05$. Tingkat kecemasan mayoritas lansia sebelum dilakukan terapi TAK yaitu cemas berat sebanyak $40,91 \%$ dan setelah dilakukan terapi TAK mayoritas lansia dengan tingkat kecemasan ringan sebanyak 47,73\%. Terdapat perbedaan kecemasan sebelum dan sesudah pemberian terapi aktivitas kelompok dengan nilai $\mathrm{P}$ sebesar 0.000 $(\mathrm{P}<0,05)$. Terapi aktivitas kelompok berpengaruh terhadap penurunan tingkat kecemasan pada lansia.
\end{abstract}

Kata Kunci : Kecemasan, lansia, terapi aktivitas kelompok. 


\section{PENDAHULUAN}

Lansia atau lanjut usia merupakan tahap terakhir dalam tahap pertumbuhan. Lanjut usia merupakan proses alami yang tidak dapat dihindari oleh setiap individu (Depsos 2006, dalam Kristyaningsih 2011). Proses menua akan terjadi perubahanperubahan baik anatomis, biologis, fisiologis maupun psikologis. Gejala-gejala kemunduran fisik antara lain kulit mulai mengendur, timbul keriput, mulai beruban, pendengaran dan penglihatan berkurang, mudah lelah, gerakan mulai lamban dan kurang lincah masalah tersebut akan berpotensi pada masalah kesehatan baik secara umum maupun kesehatan jiwa (Juniarti 2008). World Health Organization (WHO) mencatat bahwa terdapat 600 juta jiwa lansia pada tahun 2012 di seluruh dunia. Menurut data Biro Pusat Statistik (BPS), tercatat jumlah lansia Indonesia mencapai jumlah 28 juta jiwa pada tahun 2012 dari yang hanya 19 juta jiwa pada tahun 2006. Pada tahun 2025, Indonesia akan mengalami peningkatan lansia sebesar 41,4\%, yang merupakan peningkatan tertinggi di dunia (Depkes, 2012). Semakin meningkatnya jumlah lanjut usia di Indonesia akan menimbulkan permasalahan yang cukup komplek baik dari masalah fisik maupun psikososial. Masalah psikososial yang paling banyak terjadi pada lansia seperti, kesepian, perasaan sedih, depresi dan ansietas.Ansietas termasuk salah satu masalah kesehatan jiwa yang paling sering muncul (Tamher \& Noorkasiani 2009, dalam subandi dkk 2013).

Ansietas atau kecemasan merupakan perasaan takut yang tidak jelas dan tidak didukung oleh situasi.Ansietas merupakan perasaan campuran berisikan ketakutan dan keprihatinan mengenai masa-masa mendatang tanpa sebab khusus untuk ketakutan tertentu. Ansietas pada lansia memiliki gejala seperti, perasaan khawatir atau takut, mudah tersinggung, kecewa, gelisah, perasaan kehilangan, sulit tidur sepanjang malam, sering membayangkan hal-hal yang menakutkan dan rasa panik pada hal yang ringan, konflik-konflik yang ditekan dan berbagai masalah yang tidak terselesaikan akan menimbulkan ansietas (Maryam dkk 2008, dalam Soemantri dkk 2012). Perlu adanya pendampingan yang khusus terhadap lansia dan perbaikan kondisi lingkungan panti agar kecemasan pada lansia bisa menurun (Titus 2005). Terapi modalitas merupakan proses pemulihan fungsi fisik, mental-emosional, dan sosial ke arah keutuhan pribadi yang dilakukan secara holistik. Pasien sebagai manusia yang meliputi biologis, psikologis, sosial dan spritual tentu saja memiliki masalah yang multikompleks, dengan demikian penanganannya pun tentu harus multidisipliner. Pemberian terapi baik psikofarmakologi maupun keperawatan yang tepat dan akurat saja tidak cukup, tetetapi harus disusul dengan terapi modalitas yang dipilih secara teratur dan kontinu sampai berfungsinya kembali perilaku normatif yang stabil atau perilakunya adaptif.Keberhasilan terapi psikis ini sangat tergantung pada adanya komunikasi antara perawat dan pasien (Chaudhury, 2010).

Terapi modalitas yang diberikan berupa psikoterapi individu dan terapi kelompok.Terapi kelompok adalah metode pengobatan yang dilakukan ketika pasien ditemui dalam rancangan waktu tertentu dengan tenaga yang memenuhi persyaratan tertentu.Fokus terapi kelompok adalah membuat pasien menjadi sadar diri, peningkatan hubungan interpersonal ini, membuat perubahan, atau ketiganya.Terapi aktivitas kelompok dibagi sesuai dengan kebutuhan yaitu, stimulasi persepsi, stimulasi sensoris, orientasi realita, dan sosialisasi (Keliat \& Akemat, 2005).

Terapi aktivitas kelompok stimulasi persepsi bertujuan untuk melatih pasien memersepsikan stimulus yang disediakan atau stimulus yang pernah dialami.Kemampuan persepsi pasien dievaluasi dan ditingkatkan pada setiap sesi. Proses ini mengharapkan respons yang muncul dari pasien terhadap berbagai stimulus dalam kehidupan menjadi adaptif (Keliat \& Akemat, 2005).Berbagai penelitian membuktikan bahwa TAK dapat meningkatkan kemandirian pada pasien jiwa (Handayani et al, 2013).Selain itu TAK juga terbukti dapat meningkatkan ketrampilan social dasar pada pasien skizofrenia (Hartono,2012).Namun penelitian terkait efektivitas TAK terhadap kecemasan pada lansia belum pernah dilakukan.

Berdasarkan survey pendahuluan yang dilakukan pada bulan desember 2016, dari 10 lansia yang diwawancarai sebagian besar terlihat kurang fokus, pasrah, bingung dan gelisah. Berdasarkan latar belakang tersebut, peneliti tertarik untuk memberikan intervensi berupa TAK terhadap tingka kecemasan pada lansia.

\section{METODE PENELITIAN}

Jenis penelitian ini adalah quasi experiment (eksperimen semu), dengan rancangan pre-posttest group design yaitu dengan membandingkan nilai pretest dengan posttest pada kelompok intervensi. Pada penelitian ini, peneliti 
memberikan terapi aktivitas kelompok, sebelum dan sesudah terapi peneliti akan membagikan kuisioner terkait kecemasan untuk mengetahui tingkat kecemasan lansia. Penelitian ini dilakukan di Panti Jompo Panti Jompo Tresna Werdha Abdi Dharma Asih Kota Binjai. Variable penelitian Variabel terikat: penurunan tingkat kecemasan

\section{HASIL DAN PEMBAHASAN}

Penelitian ini bertujuan untuk mengetahui pengaruh terapi aktivitas kelompok terhadap ansietas pada lansia di UPT pelayanan sosial lanjut usia dan anak balita wilayah Binjai. Pelaksanaanp penelitian ini dilaksanakan pada tanggal 18 Agustus 2017 sampai dengan 20 September 2017.Jumlah sampel pada awal penelitian berjumlah 50 lansia. Namun, sebanyak 6 lansia di dropout dari penelitian karena 4 lansia tidak mengikuti treatment hingga akhir penelitian dan 2 orang tidak dihitung karena melebihi jumlah sampel sehingga jumlah sampel pada akhir penelitian sebanyak 44 lansia. Berikut karateristik responden dalam penelitian ini.

Tabel. 4.1. Distribusi Frekensi Responden berdasarkan suku di UPT pelayanan sosial lanjut usia dan anak balita wilayah Binjai

\begin{tabular}{llcc}
\hline No. & \multicolumn{1}{c}{ Suku } & Frekuensi & $\begin{array}{c}\text { Presentase } \\
(\%)\end{array}$ \\
\hline 1 & Jawa & 25 & $\mathbf{5 6 , 8 1 \%}$ \\
2 & Batak & 9 & $20,45 \%$ \\
3 & Melayu & 6 & $13,63 \%$ \\
4 & Minang & 4 & $9.11 \%$ \\
& Kabau & & \\
\hline \multirow{3}{*}{} & Total & $\mathbf{4 4}$ & $100 \%$
\end{tabular}

Berdasarkan tabel 4.1.mayoritas lansia di UPT pelayanan sosial lanjut usia dan anak balita wilayah Binjai yang menjadi responden dalam penelitian ini yaitu berasal dari suku jawa dengan presentase $56,81 \%$ dan yang terendah yaitu dari suku minangkabau dengan presentase $9,11 \%$.

Tabel 4.2. Distribusi Frekensi Responden berdasarkan jenis kelamin di UPT pelayanan sosial lanjut usia dan anak balita wilayah Binjai

\begin{tabular}{llcc}
\hline No. & \multicolumn{1}{c}{ Jenis } & Frekuensi & $\begin{array}{c}\text { Presentase } \\
(\%)\end{array}$ \\
\hline 1 & Kelamin & & $\mathbf{5 4 . 5 4 \%}$ \\
2 & Lerempuan & 24 & $45,45 \%$ \\
\hline 3 & Total & 44 & $100 \%$ \\
\hline
\end{tabular}

Berdasarkan tabel 4.2 mayoritas lansia di UPT pelayanan sosial lanjut usia dan anak balita wilayah Binjai yang menjadi responden dalam penelitian ini yaitu berjenis kelamin perempuan sebanyak $54.54 \%$.

Tabel 4.3. Distribusi Frekuensi Responden berdasarkan Agama di UPT pelayanan sosial lanjut usia dan anak balita wilayah Binjai No. Agama Frekuensi Presentase

$(\%)$

\begin{tabular}{llcc}
\hline 1 & Islam & 35 & $\mathbf{7 9 , 5 4 \%}$ \\
2 & Kristen & 9 & $20,45 \%$ \\
\hline 3 & Total & 44 & $100 \%$ \\
\hline
\end{tabular}

Berdasarkan tabel 4.3.mayoritas lansia di UPT pelayanan sosial lanjut usia dan anak balita wilayah Binjai yang menjadi responden dalam penelitian ini yaitu beragama Islam sebanyak $79,54 \%$. 
Tabel. 4.4. Distribusi Frekuensi Responden berdasarkan UmurUPT pelayanan sosial lanjut usia dan anak balita wilayah Binjai

\begin{tabular}{llcc}
\hline No. & Umur & Frekuensi & $\%$ \\
\hline 1 & $50-55$ & 3 & $6,83 \%$ \\
2 & $55-60$ & 10 & $22,72 \%$ \\
3 & $60-65$ & 12 & $27,27 \%$ \\
4 & $>65$ & 19 & $\mathbf{4 3 , 1 8 \%}$ \\
\hline & Total & $\mathbf{4 4}$ & $100 \%$ \\
\hline
\end{tabular}

Berdasarkan tabel 4.4. mayoritas lansia di UPT pelayanan sosial lanjut usia dan anak balita wilayah Binjai yang menjadi responden dalam penelitian ini yaitu berumur lebih dari 65 tahun sebanyak $43,18 \%$ dan yang terendah yaitu berumur antara 50-55 tahun sebanyak 6,83\%.

Sebelum dilakukan terapi aktivitas, dilakukan pengukuran ansietas dengan menggunakan skala Hamilton, kemudian dilakukan terapi aktivitas kelompok sebanyak 2 kali/minggu selama 4 minggu.Pada akhir pertemuan dilakukan pengukuran kecemasan kembali untuk mengetahui efektivitas terapi.Adapun kategori kecemasan sebelum dan sesudah dilakukan terapi aktivitas kelompok tersaji dalam grafik 4.1.

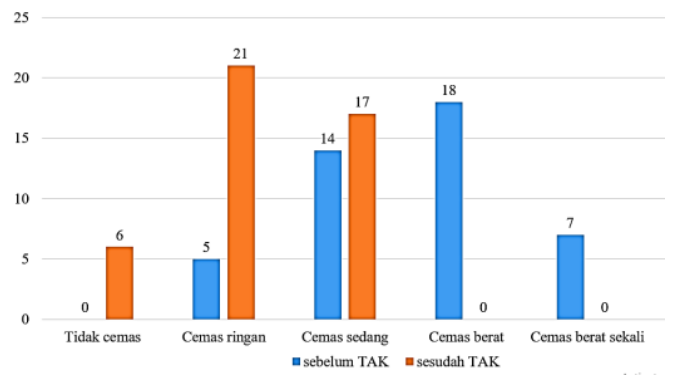

Grafik 4.1. Tingkat kecemasan sebelum dan sesudah terapi aktivitas kelompok pada lansia di UPT pelayanan sosial lanjut usia dan anak balita wilayah Binjai
Berdasarkan grafik tersebut sebelum dilakukan terapi aktivitas kelompok mayoritas lansia mengalami tingkat kecemasan yang berat sebanyak 18 orang, kemudian tingkat kecemasan sedang sebanyak 14 orang, 7 orang mengalami tingkat kecemasan berat sekali, dan 5 orang mengalami kecemasan ringan. Setelah dilakukan terapi aktivitas kelompok terjadi penurunan kecemasan yaitu mayoritas lansia dengan tingkat kecemasan ringan sebanyak 21 orang, tingkat kecemasan sedang sebanyak 17 orang, dan 6 orang yang tidak mengalami kecemasan. Selanjutnya data tingkat kecemasan tersebut dilakukan uji bivariate yaitu uji Wilcoxon untuk mengetahui perbedaan tingkat kecemasan sebelum dan setelah terapi aktivitas kelompok yang tersaji dalam tabel 4.5 .

Tabel 4.5. Pengaruh terapi aktivitas kelompok terhadap tingkat kecemasan pada lansia di UPT Pelayanan Sosial Lanjut Usia dan Anak Balita Wilayah Binjai $(n=44)$

\begin{tabular}{|c|c|c|c|c|c|}
\hline $\begin{array}{l}\text { Tingkat } \\
\text { Kecemas }\end{array}$ & \multicolumn{2}{|c|}{$\begin{array}{c}\text { Sebelum } \\
\text { TAK }\end{array}$} & \multicolumn{2}{|c|}{$\begin{array}{c}\text { Sesudah } \\
\text { TAK }\end{array}$} & \multirow[t]{2}{*}{$\begin{array}{c}\text { Nilai } \\
\mathrm{P}\end{array}$} \\
\hline & $\mathrm{N}$ & $\%$ & $\mathrm{~N}$ & $\%$ & \\
\hline $\begin{array}{l}\text { Tidak } \\
\text { cemas }\end{array}$ & 0 & 0 & 6 & $\begin{array}{c}13,6 \\
4\end{array}$ & \\
\hline $\begin{array}{l}\text { Cemas } \\
\text { ringan }\end{array}$ & 5 & $\begin{array}{l}11, \\
36\end{array}$ & 21 & $\begin{array}{c}47,7 \\
3\end{array}$ & \\
\hline $\begin{array}{l}\text { Cemas } \\
\text { sedang }\end{array}$ & 14 & $\begin{array}{l}31, \\
82\end{array}$ & 17 & $\begin{array}{c}38,6 \\
4\end{array}$ & 0.000 \\
\hline $\begin{array}{l}\text { Cemas } \\
\text { berat }\end{array}$ & 18 & $\begin{array}{l}40, \\
91\end{array}$ & 0 & 0 & \\
\hline $\begin{array}{l}\text { Cemas } \\
\text { berat } \\
\text { sekali }\end{array}$ & 7 & $\begin{array}{l}15 . \\
91\end{array}$ & 0 & 0 & \\
\hline
\end{tabular}




\begin{tabular}{lllll}
\hline Total & 44 & 100 & 44 & 100
\end{tabular}

Berdasarkan tabel 4.1. diperoleh nilai $\mathrm{P}$ sebesar 0.000, hal ini berarti nilai $\mathrm{P}$ yang diperoleh kurang dari 0.05 yang berarti terdapat perbedaan yang signifikan tingkat kecemasan sebelum dan sesudah terapi aktivitas kelompok pada lansia di UPT Pelayanan Sosial Lanjut Usia dan Anak Balita Wilayah Binjai.

lebih realistis, serta memfokuskan tugas-tugas perkembangan saat ini (McEvoy et al., 2017).Muris et al (2003) mempertegas bahwa terapi aktivitas kelompok membantu pasien untuk mengenali kecemasan, menggunakan kesadarannya untuk memanajemen kecemasannya, dan membantu pasien untuk dapat mengatasi situasi kecemasannya dengan lebih efektif.

\section{KESIMPULAN}

Sebelum pemberian terapi aktivitas kelompok mayoritas lansia di UPT Pelayanan Sosial Lanjut Usia dan Anak Balita Wilayah Binjai dengan tingkat kecemasan berat. Setelah pemberian terapi aktivitas kelompok mayoritas lansia di UPT Pelayanan Sosial Lanjut Usia dan Anak Balita Wilayah Binjai dengan tingkat kecemasan ringan. Terapi aktivitas kelompok dapat menurunkan kecemasan pada lansia di UPT Pelayanan Sosial Lanjut Usia dan Anak Balita Wilayah Binjai.

\section{DAFTAR PUSTAKA}

Annisa, D.F. dan Ifdil. 2016. Konsep Kecemasan (Anxiety) pada Lanjut Usia (Lansia). Konselor, 5(2); 93-99.
Aris, A. 2016.Pengaruh Terapi Aktivitas Kelompok (Tak)-Stimulasi Sensori Terhadap Tingkat Depresi Pada Lansia Di Upt Pelayanan Sosial Lanjut Usia Pasuruan Berlokasi Di Babat Kabupaten Lamongan. Surya, 8(2); 6-12.

Bandiyah, S 2009, Lanjut Usia Dan Keperawatan Gerontik. Nuhamedika : Yogjakarta . hal 23-25.

Departemen Kesehatan RI., (2012). Manajemen Upaya Kesehatan Usia Lanjutdi Puskesmas. Jakarta

Efendi, F. Mahfudin 2009, Keperawatan Kesehatan Komunitas. Jakarta : Salemba Medika. Hal 32-35.

Hartono, (2015). Pengaruh Terapi Aktivitas Kelompok Terhadap Peningkatan Ketrampilan Sosial Dasar Pada Pasien Skizofrenia Di Rsjd Dr. Rm. Soedjarwadi Provinsi Jawa Tengah Tahun 2015; Tesis.Magister Profesi Psikologi Universitas Ahmad Dahlan. Yogyakarta

Hawari, D., (2011). Psikiatri Manajemen Stress, Cemas \& Depresi.FK UI; Jakarta.

Heningsih, (2014). Gambaran Tingkat Ansietas Pada Lansia di Panti Wredha Dharma Bakti Kasih Surakarta., Skripsi, Program Studi Keperawatan Stikes Kusuma Husada Surakarta.

Juniarti, N, Eka, S, \& Damayanti, A. 2008; Gambaran Jenis Dan Tingkat Kesepian Pada Lansia di Balai Panti Sosial Tresna Wredha Pakutandang Ciparay Bandung, Skripsi, Fakultas Ilmu Keperawatan Universitas Padjajaran, hal 3.

Kristyaningsih, D 2011 ; Hubungan Antara Dukungan Keluarga Dengan Tingkat Depresi Pada Lansia; Jurnal Keperawatan, Volume 1; No; 1,Januari 2011-Desember 2011.hal 21-23

Khamida dan Meilisa. 2016. Terapi Aktivitas Kelompok (TAK) Stimulasi Persepsi dalam 
Menurunkan Tingkat Kecemasan Pada Lansia. Jurnal Ilmiah Kesehatan, 9(2); 121-128.

Keliat dan Akemat.(2005). Keperawatan Jiwa. Terapi Aktivitas Kelompok. Jakarta : EGC

Keliat, W.A.P., (2011). Manajemen Kasus Gangguan Jiwa: CMHN (Intermediate Course). Jakarta: EGC

Kocovski, N.L., Fleming, J.E., Rector, N.A. 2009. Mindfulness and Acceptance-Based Group Therapy for Sosial Anxiety Disorder: An Open Trial. Cognitive and Behavioral Practice, 16; 276289

Lestari, R., Wihastuti, T.A., Rahayu, B.F. 2013. Hubungan Tingkat Kecemasan dengan Tingkat Kemandirian Activities of Daily Living (ADL) Pada Lanjut Usia di Panti Werdha. Jurnal Ilmu Keperawatan, 1(2); 128-134.

Maramis, R.L. 2016.Kebermaknaan Hidup Dan Kecemasan Dalam Menghadapi Kematian Pada Lansia Di Panti Werdha Samarinda. eJournal Psikologi, 4 (3): 319-332.

Maryam,SR,dkk.2008. Mengenai Usia Lanjut dan Perawatanya. Jakarta; Salemba Medika.

Masdelita, Elita, V., Lestari, W. 2013. Pengaruh Terapi Aktivitas Kelompok (Tak) Stimulasi Sensori Terhadap Kemampuan Kerjasama Pada Pasien Dengan Masalah Isolasi Sosial. Program Studi Ilmu Keperawatan Universitas Riau.

McEvoy, P.M., Mouldsc, M.L., Grisham, J.R., Holmes, E.A., Moscovitch, D.A., Hendrie, D., Saulsman, L.M., Lipp, O.V., Kane, R.T., Rapee, R.M., Hyett, M.P., Erceg-Hurn, D.M. 2017. Assessing the efficacy of imagery-enhanced cognitive behavioral group therapy for sosial anxiety disorder: Study protocol for a randomized controlled trial.Contemporary Clinical Trials, $60 ; 34-41$

Muflih, A.S. dan Husna, A.R. 2015.Effect of Stimulation Therapy Group Activities Playing With Snakes Ladders Perception of Decrease Frequency of Hallucinations in Schizophrenic Patients. The Sun, 2(2); 35-40

Muris, P., Meesters, C., Melick, M.V. 2002.Treatment of childhood anxiety disorders: a preliminary comparison between cognitivebehavioral group therapy and a psychological placebo intervention. Journal of Behavior Therapy and Experimental Psychiatry, 33: 143-158.

Rianjani, E., Nugroho, H.A., Astuti, R. 2011. Kejadian insomnia berdasar karakteristik dan tingkat kecemasan pada lansia di panti wredha pucang gading semarang. Jurnal Keperawatan, 4(2): $194-209$

Soemantri, B, Lestari, R \& Triambadha PV 2012; Pengaruh Terapi MengenangMasa Lalu (Reminiscence Therapy) Terhadap Penurunan TingkatKecemasan Pada Lansia di Panti Wredha Pangesti Lawang.hal 30-32.

Stuart, W. G., (2006). Buku Saku Keperawatan Jiwa Edisi 5. EGC; Jakarta.

Subandi, Lestari R \& Suprianto T 2013.Pengaruh Terapi Psikoreligius TerhadapPenurunan Tingkat Ansietas Pada Lansia di UPT Pelayanan Sosial LanjutUsia Sejahtera Pandaan Pasuruan.hal 2024.

Suliswati., (2005). Konsep Dasar Keperawatan Jiwa. EGC; Jakarta

Titus Irto, Rachman Watief A, Arsyad Rahman. 2005. Gambaran Perilaku Lansia Terhadap Kecemasan di Panti Sosial Tresna Wredha 
Theodoro Makasar ; Jurnal. FKM Unhas Makasar.

Hal 1-9.

Untari, I. dan Rohmawati. 2014.

Faktor-faktor yang mempengaruhi kecemasan pada usia pertengahan dalam menghadapi proses menua (aging process). Jurnal Keperawatan, $1(2)$.

Videbeck, S. L., (2008). Buku Ajar Keperawatan Jiwa Jakarta: Buku kedokteran.EGC.

Wiyono, W. dan Widodo, A. 2010.Hubungan Antara Tingkat Kecemasan Dengan Kecenderungan Insomnia Pada LansiaDi Panti Wredha Dharma Bhakti Surakarta.Berita Ilmu Keperawatan, 2(2);87-92.

Yosep.I. (2007).Keperawatan Jiwa. Bandung : Refika Aditama 